\title{
Blood cell and metabolic profile of Nellore bulls and their correlations with residual feed intake and feed conversion ratio
}

\author{
Perfis sanguíneo e metabólico de touros Nelore e suas correlações com consumo \\ alimentar residual e taxa de conversão alimentar
}

\author{
SANTANA, Miguel Henrique de Almeida ${ }^{1}$; ROSSI JUNIOR, Paulo ${ }^{2}$; ALMEIDA, \\ Rodrigo de ${ }^{2}$; SCHUNTZEMBERGER, Amanda Massaneira de Souza ${ }^{1}$
}

\footnotetext{
${ }^{1}$ Universidade de São Paulo, Faculdade de Zootecnia e Engenharia de Alimentos, Departamento de Medicina Veterinária, Pirassununga, São Paulo, Brasil.

${ }^{2}$ Universidade Federal do Paraná, Setor de Ciências Agrárias, Curitiba, Paraná, Brasil.

*Endereço para correspondência: miguel-has@hotmail.com
}

\section{SUMMARY}

Due to the potential metabolic changes related to the residual feed intake (RFI), this study investigated the correlation of traditional RFI $\left(\mathrm{RFI}_{1}\right), \mathrm{RFI}$ adjusted for final rump fat thickness $\left(\mathrm{RFI}_{2}\right)$ and feed conversion ratio (FCR) with the metabolic and blood profiles, as well as determined the possible different classes of $\mathrm{RFI}_{1}$ and $\mathrm{RFI}_{2}$. For this purpose, 46 Nellore bulls, 22 month-old and $411 \mathrm{~kg}$ of weight at the beginning of the study were used. The animals were fed with the same diet for 84 days, and blood samples were collected every 21 days for evaluation of serum metabolites and blood cell profiles. No significant correlations were found between FCR and metabolic or blood traits, although there was a significant correlation between $\mathrm{RFI}_{1}$ and urea serum concentration. There were also differences between the RFI classes for creatinine, in which more efficient animals showed higher values. The $\mathrm{RFI}_{2}$ did not correlate with any metabolic and blood cell variable, but young bulls with smaller $\mathrm{RFI}_{2}$ had a smaller number of eosinophils when compared to animals with higher $\mathrm{RFI}_{2}$. These results suggest that animals with a high RFI can have greater energy expenditure due to protein synthesis and degradation process, resulting in a larger blood urea level.

Keywords: beef cattle, feed efficiency, metabolism

\section{RESUMO}

Em função das diversas variações metabólicas relacionadas com o consumo alimentar residual (CAR), objetivou-se nesse estudo avaliar as correlações do CAR tradicional $\left(\mathrm{CAR}_{1}\right), \mathrm{CAR}$ ajustado para deposição de gordura subcutânea na garupa $\left(\mathrm{CAR}_{2}\right)$ e da conversão alimentar (CA) com o perfil metabólico e sanguíneo, assim como verificar as possíveis diferenças das classes de $\mathrm{CAR}_{1}$ e $\mathrm{CAR}_{2}$. Para tanto, foram utilizados 46 touros da raça Nelore com 22 meses de idade e $411 \mathrm{~kg}$ no início do estudo. Os animais foram alimentados com a mesma dieta durante 84 dias, nesse período foram coletadas a cada 21 dias amostras de sangue para avaliação de metabólitos no soro e do perfil celular no sangue. Não foram encontradas correlações significativas da CA com nenhuma característica metabólica ou sanguínea, já para o $\mathrm{CAR}_{1}$ foi encontrada correlação significativa para a concentração de ureia sérica, também houve diferença entre as classes com relação à creatinina, na qual animais mais eficientes apresentaram valores superiores para essa variável. $\mathrm{O} \mathrm{CAR}_{2}$ não foi correlacionado com nenhuma variável metabólica e das células do sangue, porém animais de menor $\mathrm{CAR}_{2}$ tiveram menor quantidade de eosinófilos quando comparados com os animais de maior $\mathrm{CAR}_{2}$. Esses resultados sugerem que animais menos eficientes para CAR podem ter maior gasto energético com processos de síntese e degradação proteica corporal, devido à maior quantidade de ureia presente no sangue.

Palavras-chave: bovinos de corte, eficiência alimentar, hemograma, metabolismo 


\section{INTRODUCTION}

Profitability of any production system is related to costs and revenues resulting from the system employed. Beef cattle production systems have emphasized improvements of revenue-related aspects by improving several features for a direct yield increase (e.g., weight gain increase) and a cost reduction process to improve profitability as well. The knowledge of all the sources of variation that cause physiological differences between animals in terms of feed efficiency is still incomplete, mainly residual feed intake (RFI). Some variations are known in blood parameters (RICHARDSON et al., 2002) and metabolic characteristics (RICHARDSON et al., 2004), however, these variations explain only a small part of total feed efficiency variation in beef cattle (HERD \& ARTHUR, 2009). A thorough study of all possible processes related to this variation may lead to a more efficient and early selection for RFI (such as physiological and genetic markers). Furthermore, it can help ensure that this selection to improve the RFI will not inflict undesirable effects on progeny.

According to Richardson et al. (2004), some metabolites may indirectly indicate energy substrates (glucose and triglycerides), protein metabolism (urea, creatinephosphokinase, total plasma protein and aspartate aminotransferase) and metabolic differences due to differences in body composition (urea, creatinine and triglycerides). The blood cell profile is affected to the way animals respond to stress factors, such as the confinement period, diet changes and general weighing management. Both blood factors, metabolic and cell profile, allow to have an overview of the animal metabolism as a whole, mainly of the correlations and differences between efficiency groups for these procedures. Relationships of these parameters with RFI in Bos taurus indicus animals were not published yet. Thus, the objective of this study was to investigate the association between residual feed intake $\left(\mathrm{RFI}_{1}\right.$ and $\left.\mathrm{RFI}_{2}\right)$ and feed conversion ratio (FCR) with blood serum metabolic and hematologic traits. In addition, to evaluate the possible differences across these traits for the RFI groups (high, medium, and low) in Nellore bulls.

\section{MATERIAL AND METHODS}

This study was conducted in Guapirama, Paraná, south of Brazil, from December $22^{\text {nd }}, 2008$ to March $16^{\text {th }}, 2009$. Forty-six Nellore bulls from ten farms were evaluated with an average age of $22 \pm 2$ months of age and $409 \pm 49 \mathrm{~kg}$ of body weight at the beginning of the trial.

The study was conducted in an experimental feedlot equipped with individual pens, 2.0 meters wide by 15 meters long and dirt floor. Concrete troughs were provided with individual partitions and drinkers.

Prior to the experimental period, the animals were kept for 45 days in the experiment site for adaptation in a paddock with Palisade grass pasture (Pannicum maximum cv Mombaça) and mineral salt ad libitum to reduce effects of different diets they received in their places of origin.

After this adaptation period, the animals were sent to the feedlot where they remained for another 14 days for diet and location adaptation. Afterwards, the trial period of 84 days was started.

Animals were fed twice a day, at 8:00 a.m. and 4:00 p.m. The diet was a total 
mixed ration containing sugarcane silage and concentrate at 50:50 ratio in dry matter (DM), formulated with $70 \%$ of total digestible nutrients (TDN) and $15.2 \%$ crude protein $(\mathrm{CP})$ without the addition of any food additive or growth promoter, more datails in Santana et al. (2012).

The DM content of silage and orts were monitored weekly by composites of partial samples obtained daily and homogenized to obtain the week samples. The samples were frozen and sent to the Animal Nutrition Lab of Universidade Federal do Paraná (UFPR), Brazil, where they were dried at $55^{\circ} \mathrm{C}$ for 48 hours to determine DM of the silage and orts. The average DM content of orts, sugarcane silage, and concentrate were $34.4 \%, 25.5 \%$ and, $88.1 \%$, respectively.

The observed dry matter intake $\left(\mathrm{DMI}_{\mathrm{obs}}\right)$ was obtained by weighing daily the total diet offered and orts. Subtraction of the total diet offered by orts was adjusted to dry matter content. The daily adjustment in the diet was based on residual feed from the previous day. Orts corresponding to less than $10 \%$ of the diet were increased to $+1 \mathrm{~kg}$ of DM the next day. Orts higher than $15 \%$ of the diet were reduced to -1 $\mathrm{kg}$ of DM the following day.
The weighing procedure took place on $0 ; 21 ; 42 ; 63$ and 84 days during the experimental period, preceded by a 16hour fast. The calculation of average daily gain (ADG) was obtained by linear regression of body weight (BW) at the different individual days on feed. We also estimated individual metabolic body weight (MetBW) using data from initial (IBW) and final body weight (FBW), according to the equation:

$$
\mathrm{MetBW}=[(\mathrm{IBW}+\mathrm{FBW}) / 2]^{0.75}
$$

The predicted dry matter intake

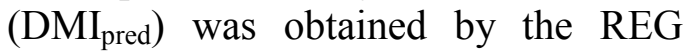
procedure of SAS statistical package version 9.3(SAS Institute ,2011) by estimating regressions of the dry matter intake $\left(\mathrm{DMI}_{\mathrm{obs}}\right)$ in average metabolic body weight (MetBW) and average daily gain (ADG). We also estimated the $\mathrm{DMI}_{\text {pred }}$ including the final rump fat thickness to the model along with the MetBW and ADG to calculate $\mathrm{RFI}_{2}$ where $\mathrm{DMI}_{\mathrm{obs}}$ was subtracted by $\mathrm{DMI}_{\text {pred2 }}$ with adjustment for final rump fat thickness $\left(\mathrm{RFT}_{\mathrm{f}}\right)$.

The $\mathrm{RFI}_{1}$ was calculated as the difference of $\mathrm{DMI}_{\text {obs }}$ by $\mathrm{DMI}_{\text {pred1 }}$. The feed conversion ratio (FCR) was obtained from direct relation of daily $\mathrm{DMI}_{\mathrm{obs}}$ by ADG.

The model for predicting DMI of the $\mathrm{RFI}_{1}$ was:

$$
\mathrm{DMI}_{\text {pred } 1}=0.15463+(0.07619 \times \mathrm{xMetBW})+(0.85989 \mathrm{xADG}) \quad\left(\mathrm{R}^{2}=0.56\right)
$$

For the $\mathrm{RFI}_{2}$ the equation to get the $\mathrm{DMI}_{\text {pred2 }}$ was:

$$
\mathrm{DMI}_{\mathrm{pred} 2}=0.16748+(0.06749 \mathrm{xMetBW})+(0.82585 \mathrm{xADG})+(0.15305 \mathrm{xRFTf}) \quad\left(\mathrm{R}^{2}=0.62\right)
$$

After determining the $\mathrm{RFI}_{1}$ and $\mathrm{RFI}_{2}$, bulls were classified into low (more efficient; <0.5 SD below the mean), medium (mid; \pm 0.5 SD from the mean), and high (less efficient; $>0.5$ SD above the mean) RFI groups.
Three blood samples for each weighing procedure of all animals were obtained by puncture of the right jugular with a $25 \times 8$ needle in $5 \mathrm{ml}$ evacuated tubes without anticoagulant for the analysis of metabolic and blood cell profiles. A sample was cooled and stored 3 hours 
after puncture and centrifuged for 5 minutes at $5000 \mathrm{rpm}$ to isolate the serum. The serum sample was frozen and sent to the Clinical Pathology lab of Universidade Federal do Paraná in Curitiba, Brazil, to determine concentrations of aspartate aminotransferase (AST), creatinephosphokinase (CPK) and creatinine (CRE). Concentrations of triglycerides (TGL), glucose (GLU) and urea (URE) were also determined through Bioclin ${ }^{\circledR}$ biochemical kits and Metrolab spectrophotometer. To ensure accuracy and control of techniques, equipment and results, reference serum Qualitrol ${ }^{\circledR}$ HS N from Merck were used.

The second blood sample was used immediately after collection. A drop of this sample was used on the plates with blood smears for differential leukocyte counts and total leukocytes (LEU). Differentiated cells, expressed as a percentage of LEU, were eosinophils (EOS), basophils (BAS), monocytes (MONO), lymphocytes (LYN) and neutrophils (NEU).

The last sample was cooled and used in erythrocyte analysis to determine total red blood cell count (RBC), average hemoglobin concentration (AHC) and hemoglobin count (HGB). Also, the average globular value (AGV) was determinate by centrifugation in microhematocrit at $2500 \mathrm{rpm}$ for 5 minutes and total plasma protein (TPP) and fibrinogen (FBN) by refractometry. Hematocrit (HCR) was determined using a microcapillary tube filled with blood. This sample was centrifuged for 5 minutes and the reading was made in the micro-hematocrit scale with values in percentage. We also calculated the ratio of neutrophils by lymphocytes (NEU/LYN).

The correlation coefficients between $\mathrm{RFI}_{1}, \mathrm{RFI}_{2}$, and $\mathrm{FCR}$ with metabolic and blood variables were computed by the CORR procedure from SAS. Simple Pearson correlations were estimated and considered significant if probabilities were lower than 5\%. The RFI group effect was analyzed by ANOVA using the GLM procedure from SAS and the adjusted means were compared with the Tukey-Kramer test. The results were interpreted as statistically significant with a $5 \%$ probability level.

\section{RESULTS AND DISCUSSION}

The values found for $\mathrm{RFI}_{1}$ and $\mathrm{RFI}_{2}$ (Table 1), regarding amplitude, were below the minimum and maximum values found by Gomes et al. (2013) for Nellore bulls $(-1.70$ and $+2.07 ;-2.72$ and $+1.54 \mathrm{~kg} \mathrm{DM} /$ day; respectively) but higher compared with Almeida (2005) who described a minimum value of 0.72 and a maximum of $+0.95 \mathrm{~kg}$ $\mathrm{DM} /$ day. The standard deviation values for RFI are similar to those found by Gomes et al. (2013) and Almeida (2005); 0.69 and $0.41 \mathrm{~kg} \mathrm{DM} /$ day, however lower than values described by Almeida et al. (2004) who found SD of $1.05 \mathrm{~kg} \mathrm{DM} /$ day. The FCR obtained in this study was similar to that found by Almeida (2005) who described an average of $8.16 \mathrm{~kg} \mathrm{DMI} / \mathrm{kg} \mathrm{ADG}$.

The greater standard deviation for RFI of Zebu cattle found by Almeida et al. (2004) was previously discussed and attributed to compensatory weight gain of animals from different origin sites. The lower values found by Almeida (2005) and Gomes et al. (2013) could be explained also by this reason, given that in these studies the animals were from the same farm. In the present study, we observed lower values of SD for RFI in Zebu cattle, even from different sites of origin. This can be explained by the 
grazing adaptive period that may have reduced this effect or also by the fact that half of these animals were from only two farms.

The phenotypical correlations of $\mathrm{RFI}_{1}$ and $\mathrm{RFI}_{2}$ with AST and CRE showed in Table 2 contradict previous results from Richardson et al. (2004), who found values for these correlations of 0.25 and -0.29, respectively. According this study, the work of Richardson and Herd (2004) found no significant correlation of RFI with TGL and GLU. There were no significant correlations $(\mathrm{P}>0.05)$ of FCR with any metabolic trait.

Table 1. Means, standard deviations, minimum and maximum values for performance, feed intake, and feed efficiency traits in Nellore bulls

\begin{tabular}{lcccc}
\hline Traits & Mean & SD & Minimum & Maximum \\
\hline Initial body weight $(\mathrm{kg})$ & 410 & 49.9 & 290 & 510 \\
Final body weight $(\mathrm{kg})$ & 504 & 50.4 & 398 & 614 \\
Average daily gain $\left(\mathrm{kg} /\right.$ day) $_{\text {Dry matter intake }_{\text {obs }}(\mathrm{kg} / \text { day) }}$ & 1.17 & 0.22 & 0.78 & 1.80 \\
Dry matter intake $(\% \mathrm{BW})_{\text {Feed conversion ratio }}$ & 8.68 & 0.87 & 7.10 & 10.56 \\
Residual feed intake $_{1}(\mathrm{~kg} \mathrm{DM} /$ day) & 1.91 & 0.15 & 1.57 & 2.30 \\
Residual feed intake $_{2}(\mathrm{~kg} \mathrm{DM} /$ day) & 8.03 & 1.64 & 5.07 & 13.03 \\
\hline
\end{tabular}

Table 2. Means and standard deviations (SD) of blood metabolites and their correlations with $\mathrm{RFI}_{1}\left(\mathrm{r}_{\mathrm{RFI} 1}\right), \mathrm{RFI}_{2}\left(\mathrm{r}_{\mathrm{RFI} 2}\right)$ and FCR $\left(\mathrm{r}_{\mathrm{FCR}}\right)$

\begin{tabular}{lccccc}
\hline Variables & Means & $\mathrm{SD}$ & $\mathrm{r}_{\text {RFI1 }}$ & $\mathrm{r}_{\text {RFI2 }}$ & $\mathrm{r}_{\mathrm{FCR}}$ \\
\hline Aspartate aminotranspherase (U/L) & 119.43 & 19.34 & -0.26 & -0.25 & 0.26 \\
Creatine phosphokinase (U/L) & 611 & 62.4 & -0.28 & -0.29 & 0.14 \\
Creatinine (mg/dL) & 1.85 & 0.19 & -0.11 & -0.11 & -0.01 \\
Triglycerides (mg/dL) & 18.78 & 5.14 & 0.18 & 0.19 & -0.18 \\
Glucose (mg/dL) & 90.18 & 13.40 & 0.05 & 0.10 & -0.07 \\
Urea (mg/dL) & 52.41 & 5.83 & $0.29 *$ & 0.21 & 0.13 \\
\hline
\end{tabular}

*P $<0.05$.

Clarke et al. (1996) reported higher plasma urea concentrations in animals with lower lean tissue growth and increased deposition of subcutaneous fat in the carcass. The results of the correlations between RFI and carcass traits measured by ultrasound of the same animals in the current study (SANTANA et al., 2012) support this hypothesis because the less efficient young bulls had greater final and gain in deposition of subcutaneous fat over the Biceps femoris muscle over the test.

In the present study, it was found a significant correlation $(\mathrm{P}<0.05)$ only between URE and $\mathrm{RFI}_{1}$. The direction of the correlation shows that more efficient animals for $\mathrm{RFI}_{1}$ have lower URE compared with less efficient animals. Similar to the present study, Richardson et al. (2004) described a trend $(\mathrm{P}<0.10)$ in which animals from a 
previously selected progeny for better RFI also had lower urea concentrations at weaning, however this trend was not confirmed at older ages. Kelly et al. (2010) found no significant correlation $(\mathrm{P}<0.05)$ of RFI with urea and glucose in crossbred heifers.

Urea concentration is related to body composition probably due to a difference in the protein catabolism and anabolism processes. Additionally, depends on the ruminal protein:energy ratio, but, even the diet of the experiment contains a relatively high protein content, the protein:energy ratio in this case was the same for all bulls. Theoretically, less efficient animals have higher protein breakdown rates, which are processes that increase energy use for the maintenance of these animals, offering fewer nutrients for production. According to Mortimore \& Poso (1987), urea increase is mainly due to a rise in the catabolism of amino acids. In fact, evidence that less efficient animals have higher protein degradation is reported in the literature (RICHARDSON et al., 1996).

Another possible reason for the lower concentration of urea in more efficient animals is that they have a more efficient ability to utilize sources of dietary carbohydrates available in the rumen. Some authors have reported differences in carbohydrates digestibility of cattle with different values for RFI (CHANNON et al., 2004; NKRUMAH et al., 2006).

With a poorer use of readily available carbohydrates in the rumen by animals with high RFI the energy generated for microbial growth is not synchronized with readily available protein sources. However, other factors can influence urea levels in cattle blood, such as feed intake. With an increased dry matter intake, there is a concomitant increase in urea levels (BERSCHAUER et al., 1983). This statement is consistent with the correlation found by Richardson et al. (2004), who reported negative correlations between urea and RFI. Therefore, in addition to the low magnitude of the correlation found in this study and to the different mechanisms that affect blood urea concentrations, it is necessary to better understand how each of these mechanisms influences RFI variation in Zebu cattle.

Despite the low correlation between blood creatinine concentration RFI, a statistical difference between animals with high and low $\mathrm{RFI}_{1}$ was observed (Table 3). More efficient animals had greater $(\mathrm{P}<0.05)$ serum creatinine. This may indicate that more efficient animals have greater muscle mass. According to Richardson et al. (2004), the association obtained between RFI and creatinine was negative, confirming that animals with better RFI may have greater muscle mass.

AST and CPK were not statistically correlated with RFI (Table 3 and Table 4). AST is a measure of the hepatic function related to the metabolism of amino acids, however the correlation obtained by Richardson et al. (2004), $(r=0.25)$ showed the opposite direction to that obtained in this study. Nevertheless, the RFI correlation with AST in studies with bulls after a stressful situation (transport) followed the same direction of the correlation in this study. This could indicate that when more efficient animals are stressed, they have a higher AST concentration in blood serum. CPK is a key metabolite in the energy transport of muscle cells and is found in greater quantities in animals with higher muscle growth. 
Rev. Bras. Saúde Prod. Anim., Salvador, v.14, n.3, p.527-537 jul./set., 2013 http://www.rbspa.ufba.br ISSN 15199940

Table 3. Characterization of metabolic profile of Nellore young bulls with high, medium and low $\mathrm{RFI}_{1}$

\begin{tabular}{lccccc}
\hline \multirow{2}{*}{ Variables } & \multicolumn{3}{c}{ RFI $_{1}$ group $^{\mathrm{I}}$} & \multirow{2}{*}{ SEM $^{2}$} & \multirow{2}{*}{$\mathrm{P}>\mathrm{F}$} \\
\cline { 2 - 4 } & High & Medium & Low & & \\
\hline Number of bulls & 13 & 17 & 16 & - & - \\
Aspartate aminotranspherase (U/L) & $117.00^{\mathrm{a}}$ & $116.53^{\mathrm{a}}$ & $124.50^{\mathrm{a}}$ & 2.85 & 0.44 \\
Creatine phosphokinase (U/L) & $425^{\mathrm{a}}$ & $653^{\mathrm{a}}$ & $717^{\mathrm{a}}$ & 91.94 & 0.44 \\
Creatinine (mg/dL) & $1.77^{\mathrm{a}}$ & $1.91^{\mathrm{b}}$ & $1.85^{\mathrm{b}}$ & 0.03 & 0.05 \\
Triglycerides (mg/dL) & $18.45^{\mathrm{a}}$ & $19.66^{\mathrm{a}}$ & $18.11^{\mathrm{a}}$ & 0.76 & 0.67 \\
Glucose (mg/dL) & $87.96^{\mathrm{a}}$ & $94.15^{\mathrm{a}}$ & $87.59^{\mathrm{a}}$ & 1.98 & 0.30 \\
Urea (mg/dL) & $54.46^{\mathrm{a}}$ & $52.74^{\mathrm{a}}$ & $50.38^{\mathrm{a}}$ & 0.86 & 0.17 \\
\hline
\end{tabular}

${ }^{1}$ Least square means by Tukey-Kramer test within a row with different superscripts differ $(\mathrm{P}<0.05)$;

${ }^{2}$ Standard error of the mean.

Table 4. Characterization of metabolic profile of Nellore young bulls with high, medium and low $\mathrm{RFI}_{2}$

\begin{tabular}{|c|c|c|c|c|c|}
\hline \multirow{2}{*}{ Variables } & \multicolumn{3}{|c|}{$\mathrm{RFI}_{1}$ group $^{\mathrm{I}}$} & \multirow{2}{*}{ SEM $^{2}$} & \multirow{2}{*}{$\mathrm{P}>\mathrm{F}$} \\
\hline & High & Medium & Low & & \\
\hline Number of bulls & 10 & 23 & 13 & & \\
\hline Aspartate aminotranspherase $(\mathrm{U} / \mathrm{L})$ & $119.40^{\mathrm{a}}$ & $117.30^{\mathrm{a}}$ & $123.23^{\mathrm{a}}$ & 2.85 & 0.69 \\
\hline Creatine phosphokinase (U/L) & $564^{\mathrm{a}}$ & $565^{\mathrm{a}}$ & $727^{\mathrm{a}}$ & 91.94 & 0.74 \\
\hline Creatinine $(\mathrm{mg} / \mathrm{dL})$ & $1.77^{\mathrm{a}}$ & $1.87^{\mathrm{a}}$ & $1.85^{\mathrm{a}}$ & 0.03 & 0.59 \\
\hline Triglycerides (mg/dL) & $20.03^{\mathrm{a}}$ & $19.28^{\mathrm{a}}$ & $16.94^{\mathrm{a}}$ & 0.76 & 0.30 \\
\hline Glucose (mg/dL) & $88.15^{\mathrm{a}}$ & $91.04^{\mathrm{a}}$ & $89.99^{\mathrm{a}}$ & 1.98 & 0.86 \\
\hline Urea $(\mathrm{mg} / \mathrm{dL})$ & $55.07^{\mathrm{a}}$ & $51.72^{\mathrm{a}}$ & $51.56^{\mathrm{a}}$ & 0.86 & 0.27 \\
\hline
\end{tabular}

There were no significant correlations of $\mathrm{RFI}_{1}, \mathrm{RFI}_{2}$ and $\mathrm{FCR}$ with any hematological variable in this study (Table 5). Richardson et al. (2002) found genotypic correlations of RFI with the blood cell profile (LEU, HGB, HCR and LYN) in a study with cattle of European origin. These evidences were not found in the phenotypic correlations described in this study. Richardson et al. (2002) found no FCR genotypic correlation with any blood characteristic corroborating the results obtained in this study.

There were no statistical differences of variables for blood cell profiles between the efficiency groups for $\mathrm{RFI}_{1}$ and $\mathrm{RFI}_{2}$ (Table 6 and Table 7). These results agree with those obtained by Gomes et al. (2011), who found no significant differences in the profile of animal blood cells with low or high RFI. On the other hand, Richardson et al. (1996) and Richardson et al. (2002) described differences in blood characteristics (LEU, HGB, HCR and LYN) measured in progeny of bulls with divergent average genetic values for RFI. Only an increase in the number of EOS in less efficient animals for $\mathrm{RFI}_{2}$ was observed, which might be attributed to a possible reaction to stress of less efficient animals.

Many studies have tried to correlate blood cells with traits of economic interests to try to identify easy-to- 
measure phenotypic markers for an indirect selection. The changes found by Richardson et al. (2002) in hematological profile are a possible indication that less efficient animals are more stressed, but this theory was not confirmed by the results showed in this study. Possibly, the hematological parameters were not affected in this study due to the long period of adaptation performed first in pasture and then in feedlot before the trial itself. This period of adaptation may have caused the bulls did not express a great stress during the experiment, so it is not possible to see major changes in the blood profile of them.

Table 5. Means and standard deviations of the blood cell profile and their correlations with RFI ( $\mathrm{r}_{\mathrm{RFI} 1}$ and $\left.\mathrm{r}_{\mathrm{RFI} 2}\right)$ and FCR $\left(\mathrm{r}_{\mathrm{FCR}}\right)$

\begin{tabular}{lccccc}
\hline Traits & Mean & $\mathrm{SD}$ & $\mathrm{r}_{\text {RFI1 }}$ & $\mathrm{r}_{\text {RFI2 }}$ & $\mathrm{r}_{\mathrm{FCR}}$ \\
\hline Hematocrit (\%) & 13.52 & 1.28 & -0.10 & -0.07 & 0.13 \\
Total plasma protein (g/dL) & 6.90 & 0.34 & 0.15 & 0.23 & 0.07 \\
Fibrinogen (g/dL) & 0.35 & 0.11 & 0.12 & 0.10 & -0.18 \\
Hemoglobin count (g/dL) & 13.52 & 1.28 & -0.12 & -0.07 & 0.04 \\
Average globular value (fL) & 44.54 & 5.99 & 0.12 & 0.14 & 0.24 \\
Hemoglobin concentration (\%) & 34.72 & 2.29 & -0.04 & -0.01 & -0.17 \\
Red blood cell (10\%/uL) & 8.73 & 1.01 & -0.18 & -0.15 & -0.13 \\
Leukocytes (10/uL) & 9280 & 1699 & -0.02 & 0.05 & 0.24 \\
Eosinophils (\%) & 3.33 & 3.08 & 0.11 & 0.15 & 0.12 \\
Basophils (\%) & 0.06 & 0.15 & 0.26 & 0.21 & -0.08 \\
Monocytes (\%) & 4.16 & 2.13 & -0.03 & 0.01 & 0.12 \\
Lymphocytes (\%) & 58.19 & 8.31 & -0.03 & -0.07 & -0.11 \\
Neutrophils (\%) & 34.27 & 7.83 & -0.01 & 0.01 & 0.04 \\
NEU/LYN & 0.62 & 0.22 & 0.01 & 0.04 & 0.06 \\
\hline
\end{tabular}

*Correlation coefficients are significantly different from zero $(\mathrm{P}<0.05)$.

Table 6. Characterization of blood cell profile traits of Nellore young bulls with high, medium and low $\mathrm{RFI}_{1}$

\begin{tabular}{lccccc}
\hline \multirow{2}{*}{ Traits } & \multicolumn{3}{c}{ RFI $_{1}$ group $^{\mathrm{l}}$} & \multirow{2}{*}{ SEM $^{2}$} & $\mathrm{P}>\mathrm{F}$ \\
\cline { 2 - 4 } & High & Medium & Low & & \\
\hline Hematocrit (\%) & $37.97^{\mathrm{a}}$ & $39.59^{\mathrm{a}}$ & $39.35^{\mathrm{a}}$ & 0.56 & 0.48 \\
Total plasma protein (g/dL) & $7.00^{\mathrm{a}}$ & $6.83^{\mathrm{a}}$ & $6.91^{\mathrm{a}}$ & 0.05 & 0.41 \\
Fibrinogen (g/dL) & $0.38^{\mathrm{a}}$ & $0.32^{\mathrm{a}}$ & $0.36^{\mathrm{a}}$ & 0.16 & 0.32 \\
Hemoglobin count (g/dL) & $13.26^{\mathrm{a}}$ & $13.53^{\mathrm{a}}$ & $13.71^{\mathrm{a}}$ & 0.19 & 0.66 \\
Average globular value (fL) & $45.44^{\mathrm{a}}$ & $44.62^{\mathrm{a}}$ & $43.72^{\mathrm{a}}$ & 0.88 & 0.75 \\
Hemoglobin concentration (\%) & $34.99^{\mathrm{a}}$ & $34.25^{\mathrm{a}}$ & $40.00^{\mathrm{a}}$ & 0.33 & 0.58 \\
Red blood cell $\left(10^{9} / \mathrm{mL}\right)$ & $8.51^{\mathrm{a}}$ & $8.66^{\mathrm{a}}$ & $8.98^{\mathrm{a}}$ & 0.15 & 0.44 \\
Leukocytes $(10 / \mathrm{mL})$ & $9631^{\mathrm{a}}$ & $8904^{\mathrm{a}}$ & $9395^{\mathrm{a}}$ & 250.47 & 0.49 \\
Eosinophils (\%) & $3.74^{\mathrm{a}}$ & $3.30^{\mathrm{a}}$ & $3.02^{\mathrm{a}}$ & 0.45 & 0.83 \\
Basophils (\%) & $0.08^{\mathrm{a}}$ & $0.06^{\mathrm{a}}$ & $0.04^{\mathrm{a}}$ & 0.02 & 0.81 \\
Monocytes (\%) & $4.05^{\mathrm{a}}$ & $4.02^{\mathrm{a}}$ & $4.40^{\mathrm{a}}$ & 0.31 & 0.86 \\
Lymphocytes (\%) & $60.69^{\mathrm{a}}$ & $55.71^{\mathrm{a}}$ & $58.79^{\mathrm{a}}$ & 1.23 & 0.25 \\
Neutrophils (\%) & $31.44^{\mathrm{a}}$ & $36.92^{\mathrm{a}}$ & $33.75^{\mathrm{a}}$ & 1.15 & 0.16 \\
NEU/LYN & $0.54^{\mathrm{a}}$ & $0.70^{\mathrm{a}}$ & $0.59^{\mathrm{a}}$ & 0.17 & 0.14 \\
\hline
\end{tabular}

${ }^{1}$ Least square means by Tukey-Kramer test within a row with different superscripts differ $(\mathrm{P}<0.05)$;

${ }^{2}$ Standard error of the mean. 
Rev. Bras. Saúde Prod. Anim., Salvador, v.14, n.3, p.527-537 jul./set., 2013 http://www.rbspa.ufba.br ISSN 15199940

Table 7. Characterization of blood cell profile traits of Nellore young bulls with high, medium and low $\mathrm{RFI}_{2}$

\begin{tabular}{lccccc}
\hline \multirow{2}{*}{ Traits } & \multicolumn{3}{c}{ RFI $_{2 \text { group }}{ }^{1}$} & \multirow{2}{*}{ SEM $^{2}$} & \multirow{2}{*}{$\mathrm{P}>\mathrm{F}$} \\
\cline { 2 - 4 } & High & Medium & Low & & \\
\hline Hematocrit (\%) & $38.33^{\mathrm{a}}$ & $38.84^{\mathrm{a}}$ & $39.97^{\mathrm{a}}$ & 0.56 & 0.56 \\
Total plasma protein (g/dL) & $7.06^{\mathrm{a}}$ & $6.87^{\mathrm{a}}$ & $6.85^{\mathrm{a}}$ & 0.05 & 0.28 \\
Fibrinogen (g/dL) & $0.37^{\mathrm{a}}$ & $0.35^{\mathrm{a}}$ & $0.35^{\mathrm{a}}$ & 0.16 & 0.89 \\
Hemoglobin count (g/dL) & $13.30^{\mathrm{a}}$ & $13.42^{\mathrm{a}}$ & $13.86^{\mathrm{a}}$ & 0.19 & 0.52 \\
Average globular value (fL) & $46.86^{\mathrm{a}}$ & $44.67^{\mathrm{a}}$ & $42.52^{\mathrm{a}}$ & 0.88 & 0.23 \\
Hemoglobin concentration (\%) & $34.72^{\mathrm{a}}$ & $34.63^{\mathrm{a}}$ & $34.87^{\mathrm{a}}$ & 0.33 & 0.96 \\
Red blood cell (10\%/mL) & $8.34^{\mathrm{a}}$ & $8.69^{\mathrm{a}}$ & $9.09^{\mathrm{a}}$ & 0.15 & 0.21 \\
Leukocytes $(10 / \mathrm{mL})$ & $9992^{\mathrm{a}}$ & $8963^{\mathrm{a}}$ & $9370^{\mathrm{a}}$ & 250.47 & 0.35 \\
Eosinophils (\%) & $5.67^{\mathrm{a}}$ & $2.51^{\mathrm{b}}$ & $2.97^{\mathrm{b}}$ & 0.45 & 0.02 \\
Basophils (\%) & $0.10^{\mathrm{a}}$ & $0.03^{\mathrm{a}}$ & $0.08^{\mathrm{a}}$ & 0.02 & 0.38 \\
Monocytes (\%) & $4.13^{\mathrm{a}}$ & $4.10^{\mathrm{a}}$ & $4.28^{\mathrm{a}}$ & 0.31 & 0.97 \\
Lymphocytes (\%) & $56.20^{\mathrm{a}}$ & $58.97^{\mathrm{a}}$ & $58.33^{\mathrm{a}}$ & 1.23 & 0.69 \\
Neutrophils $(\%)$ & $33.90^{\mathrm{a}}$ & $34.39^{\mathrm{a}}$ & $34.33^{\mathrm{a}}$ & 1.15 & 0.99 \\
NEU/LYN & $0.64^{\mathrm{a}}$ & $0.61^{\mathrm{a}}$ & $0.61^{\mathrm{a}}$ & 0.17 & 0.92 \\
\hline
\end{tabular}

${ }^{1}$ Least square means by Tukey-Kramer test within a row with different superscripts differ $(\mathrm{P}<0.05)$;

${ }^{2}$ Standard error of the mean.

The present study identified urea as a trait significantly associated with feed efficiency $\left(\mathrm{RFI}_{1}\right)$. This association may indicate differences in body composition, in the protein degradation and synthesis rates.

The blood cell profiles of Nellore bulls do not seem to change with different values of feed efficiency measured by feed conversion ratio and residual feed intake. Residual feed intake does not seem to negatively influence the metabolism of beef cattle.

\section{ACKNOWLEDGMENTS}

The authors gratefully acknowledge Núcleo de Criadores de Nelore do Norte do Paraná, and the Estância Vovó Laura, which funded and allocated the present study.

\section{REFERENCES}

ALMEIDA, R.; LANNA, D.P.D.; LEME, P.R. Consumo alimentar residual: um novo parâmetro para avaliar a eficiência alimentar de bovinos de corte. In: REUNIÃO ANUAL DA SOCIEDADE BRASILEIRA DE ZOOTECNIA, 41., Campo Grande, MS. Anais... Campo Grande, MS: SBZ, 2004. v. 41, p.03-14.

\section{ALMEIDA, R. Consumo e eficiência alimentar de bovinos em crescimento. 2005. 181p. Tese (Doutorado) - Escola Superior de Agricultura "Luiz de Queiroz”, Universidade de São Paulo, Piracicaba.}

BERSCHAUER, F.; CLOSE, W.H.; STEPHENS, D.B. The influence of protein: energy value of the ration and level of feed intake on the energy and nitrogen metabolism of the growing pig. 2. $\mathrm{N}$ metabolism at two environmental 
Rev. Bras. Saúde Prod. Anim., Salvador, v.14, n.3, p.527-537 jul./set., 2013 http://www.rbspa.ufba.br ISSN 15199940

temperatures. British Journal of

Nutrition, v.49, p.271-283, 1983.

CHANNON, A.F.; ROWE, J.B.;

HERD, R.M. Genetic variation in starch digestion in feedlot cattle and its association with residual feed intake.

Australian Journal of Experimental Agriculture, v.44, p.469-474, 2004.

CLARKE, J.N. Repeatibilities of blood plasma metabolites and their associations with leanness in genotypes showing a wide divergence in carcass composition. New Zealand Society of Animal Prodution, v.56, p.180-183, 1996.

GOMES, R.C.; SIQUEIRA, R.F.; BALLOU, M.A.; STELA, T.R.; LEME, P.R. Hematological profile of beef cattle with divergent residual feed intake, following feed deprivation. Pesquisa Agropecuária Brasileira, v.46, p.1105-1111, 2011.

GOMES, R.C.; SAINZ, R.D.; LEME, P.R. Protein metabolism, feed energy partitioning, behavior patterns and plasma cortisol in Nellore steers with high and low residual feed intake.

Revista Brasileira de Zootecnia, v.42, p.44-50, 2013.

HERD, R.; ARTHUR, P.F.

Physiological basis for residual feed intake. Journal of Animal Science, v.87, p.64-71, 2009. Suppl.

KELLY, A.K.; McGEE, M.; CREWS JUNIOR, D.H.; FAHEY, A.G.; WYLIE, A.R.; KENNY, D.A. Effect of divergence in residual feed intake on feeding behavior, blood metabolic variables, and body composition traits in growing beef heifers. Journal of Animal Science, v.88, p.109-123, 2010.
MORTIMORE, G.E.; POSO, A.R. Intracellular protein catabolism and its control during nutrient deprivation and supply. Annual Review of Nutrition, v.7, p.539-544, 1987.

NKRUMAH, J.D.; OKINE, E.K.; MATHISON, G.W.; SCHMID, K.; LI, C.; BASARAB, J.A.; PRICE, M.A.; WANG, Z.; MOORE, S.S.

Relationships of feedlot feed efficiency, performance, and feeding behavior with metabolic rate, methane production, and energy partitioning in beef cattle.

Journal of Animal Science, v.84, p.145-153, 2006.

RICHARDSON, E.C.; HERD, R.M.; ARTHUR, P.F.; WRIGHT, J.; XU, G.; DIBLEY, K.; ODDY, V.H. Possible physiological indicators for net feed conversion efficiency in beef cattle. In: AUSTRALIAN OCIETY OF ANIMAL PRODUCTION, 1996, Autralia. Proceedings. Australian: SAP, 1996. v. 21, p.103-106.

RICHARDSON, E.C.; HERD, R.M.; COLDITZ, I.G.; ARCHER, J.A.; ARTHUR, P.F. Blood cell profiles of steer progeny from parents selected for and against residual feed intake.

Australian Journal of Experimental Agriculture, v.42, p.901-908, 2002.

RICHARDSON, E.C.; HERD, R.M. Biological basis for variation in residual feed intake in beef cattle. 2. Synthesis of results following divergent selection. Australian Journal of Experimental Agriculture, v.44, p.431-440, 2004.

RICHARDSON, E.C.; HERD, R.M.; ARCHER, J.A.; ARTHUR, P.F. Metabolic differences in Angus steers divergently selected for residual feed intake. Australian Journal of Experimental Agriculture, v.44, p.441-452, 2004. 
Rev. Bras. Saúde Prod. Anim., Salvador, v.14, n.3, p.527-537 jul./set., 2013 http://www.rbspa.ufba.br ISSN 15199940

SANTANA, M.H.A.; ROSSI JUNIOR, P.; ALMEIDA, R.; CUCCO, D.C. Feed efficiency and its correlations with carcass traits measured by ultrasound in Nellore bulls. Livestock Science, v.145, p.252-257, 2012.

SAS Institute. SAS/STAT ®9.3 User's

Guide Release. Cary, NC, 2011.

Data de recebimento: 21/03/2013

Data de aprovação: 13/09/2013 